\title{
Hubungan Antara Dukungan Sosial Keluarga dengan Penerimaan Diri Individu yang Mengalami Asma
}

\author{
Ni Made Sintya Noviana Utami \\ Program Studi Psikologi, Fakultas Kedokteran, Universitas Udayana \\ sintya_noviana@yahoo.com
}

\begin{abstract}
Abstrak
Asma adalah sakit sesak nafas akibat adanya penyempitan saluran nafas. Penyakit ini tidak dapat disembuhkan melainkan hanya dikontrol kekambuhannya sehingga menimbulkan dampak fisik maupun psikologis pada individu yang mengalaminya. Individu cenderung sulit untuk menerima keadaan diri ketika didiagnosa mengalami suatu penyakit kronis. Dukungan sosial keluarga tentu sangat dibutuhkan untuk menghadapi situasi sulit yang dihadapi oleh individu yang mengalami asma. Berdasarkan latar belakang tersebut peneliti merumuskan masalah apakah terdapat hubungan antara dukungan sosial keluarga dengan penerimaan diri individu yang mengalami asma.

Penelitian ini merupakan penelitian kuantitatif dengan metode korelasi. Sampel pada penelitian ini adalah 105 individu yang mengalami asma di Rumah Sakit Sanjiwani Gianyar yang dipilih dengan teknik sistematik random sampling. Alat pengumpulan data dilakukan dengan menggunakan kuesioner. Uji validitas kuesioner dukungan sosial keluarga menunjukkan terdapat 5 pernyataan gugur dan 27 pernyataan valid dari 32 pernyataan, dengan koefisien reliabilitas sebesar 0,896 . Uji validitas kuesioner penerimaan diri menunjukkan terdapat 12 pernyataan gugur dan 30 pernyataan valid dari 42 pernytaan, dengan koefisien reliabilitas sebesar 0,899. Analisis data menggunakan analisis Pearson Product Moment. Hasil penelitian menunjukkan nilai $\mathrm{r}$ sebesar 0,687 dengan p sebesar 0,000. Berdasarkan hasil diperoleh maka dapat disimpulkan bahwa terdapat hubungan yang positif antara dukungan sosial keluarga dengan penerimaan diri individu yang mengalami asma.
\end{abstract}

Kata kunci: Dukungan Sosial Keluarga, Penerimaan Diri

\begin{abstract}
Asthma is an inflammatory disease caused by narrowing of the respiratory tract. This disease can not be cured but its relapse can be controled. It will provide physiological and psychological impact to individual with asthma. That individual hardly tends to accept his or her self when diagnosed with chronic disease. Family social support will be needed to cope with the hard situation faced by individual with asthma. According to that, researcher formulates the problem, is there relationship between family social support and self acceptance of individuals with asthma.

This research uses quantitative approach with correlation method. Samples in this research are 105 people suffer from asthma in Sanjiwani Hospital, Gianyar, who were chosen by systematic random sampling. The data are collected by questionnaire. Validity test of items of the family social support questionnaire shows there are 5 invalid items and 27 valid items from 32 items, and its reliability coefficient is 0,896 . Validity test of items of the self acceptance questionnaire shows there are 12 invalid items and 30 valid items from 42 items, and its reliability coefficient is 0,899 Data analysis by Pearson's product moment. Found coefficient correlation in this research is 0,687 with $p$ value 0,000 . Thus, there is positive relationship between family social support and self acceptance of individuals with ashtma.
\end{abstract}

Keywords: family social support, self acceptance 


\section{LATAR BELAKANG}

Asma merupakan keadaan sakit sesak nafas dikarenakan terjadinya aktivitas berlebih terhadap rangsangan tertentu sehingga menyebabkan peradangan dan penyempitan pada saluran nafas yang mengalirkan oksigen ke paru-paru dan rongga dada (Admin, 2012). World Health Organization (WHO) memperkirakan di tahun 2005 terdapat 255 ribu individu meninggal di dunia karena asma. Hasil penelitian International Study on Asthma and Alergies in Childhood pada tahun 2005 juga menunjukkan bahwa prevalensi gejala penyakit asma melonjak dari sebesar 4,2\% menjadi 5,4\% dan merupakan penyebab kematian ke delapan di Indonesia (Mjundi, 2012).

Menurut Yunus (dalam Wahyudi, 2012), asma merupakan penyakit kronis yang tidak dapat disembuhkan. Obat-obatan yang dikonsumsi oleh individu yang mengalami asma tidak dapat menyembuhkan penyakit asma namun hanya menekan gejala kekambuhan asma. Kekambuhan asma dapat ditandai dengan berbagai gejala seperti batuk, bunyi nafas mengikik, terjadi penyempitan pada rongga dada, nafas cenderung pendek, mudah lelah setelah berolahraga dan mengalami kesulitan tidur akibat batuk dan kesulitan bernafas (Meetdoctor, 2012). Berbagai gejala yang dialami dapat menjadi lebih buruk apabila terjadi respon imun yang buruk. Antibodi yang dihasilkan oleh sistem imun yaitu IgE menyerang sel-sel mast dalam paru-paru yang mengakibatkan terjadinya ikatan antigen dengan antibodi yang kemudian akan menyebabkan pelepasan produk sel-sel mast yang disebut mediator seperti histamin, bradikinin, dan prostaglandin serta anafilaksis. Pelepasan mediator ini dalam jaringan paru-paru mempengaruhi otot polos dan kelenjar jalan nafas yang kemudian menyebabkan pembengkakan membran mukosa, dan pembentukan mukus (cairan lengket dan tebal yang disekresikan oleh membran dan kelenjar mukosa) yang sangat banyak. Pembentukan mukus yang sangat banyak dapat menyebabkan penyumbatan bronkiolus yang dapat memperberat serangan asma.

Serangan asma yang dialami oleh individu dapat disebabkan oleh tiga faktor pemicu menurut Davidson, Neale, dan Kring (2006) yaitu alergen, infeksi dan psikologis. Kekambuhan asma yang disebabkan oleh alergen terjadi karena sel-sel pada saluran pernafasan sangat sensitif terhadap zat-zat tertentu seperti serbuk sari, bulu, kecoa, polusi dan asap rokok. Berbeda dengan alergen, kekambuhan yang diakibatkan oleh infeksi terjadi karena adanya infeksi pada saluran pernafasan seperti bronkitis akut. Sedangkan faktor pemicu kekambuhan asma yang disebabkan oleh faktor psikologis terjadi ketika individu yang mengalami asma merasa frustrasi, depresi, cemas yang berlebihan, dan tidak dapat menerima keadaan diri.

Adanya berbagai faktor pemicu kekambuhan asma membuat pola hidup individu menjadi berubah karena harus menyesuaikan diri dengan perubahan-perubahan fisiologis yang disebabkan oleh asma dan menghindari faktor pemicu kekambuhan asma. Hal ini dapat memberikan dampak pada fisik maupun psikologis individu. Dampak fisik yang cenderung dialami oleh individu yang mengalami asma seperti kesulitan bernafas, bunyi nafas mengikik dan terengah-engah, mudah merasa lelah, kesulitan berbicara ketika serangan asma kambuh, dan kesulitan tidur. Berbagai dampak fisik yang dialami individu yang mengalami asma juga cenderung menimbulkan perubahan pada bentuk fisik seperti terbentuk lingkaran mengelilingi mata, ukuran hidung bertambah kecil, bahu terlihat meninggi, dan gigi bagian atas terlihat menonjol. Perubahan fisik yang terjadi pada individu yang mengalami asma akan berpengaruh terhadap menurunnya rasa percaya diri individu (Cutetomatto, 2012).

Selain dapat berpengaruh terhadap menurunnya rasa percaya diri individu, asma juga dapat menimbulkan dampak psikologis pada individu seperti rasa cemas, depresi, takut, merasa diri berbeda dengan individu lain, merasa tidak berdaya, merasa terkekang dan tidak dapat bebas, terbebani dalam masalah finansial, merasa terikat karena harus rutin minum obat, dan khawatir merepotkan keluarga karena terganggu dengan sesak nafas dan batuk (Cutetomatto, 2012). Hal tersebut dapat memicu timbulnya stres dalam kehidupan individu, sehingga sakit yang dialami oleh individu menjadi bertambah parah dan prognosis menjadi buruk (Cahyani, 2013; Miller dalam Dwitantyanov, 2012). Stres yang dialami oleh individu dapat merangsang sistem imun untuk memproduksi hormon stres seperti glukokortikoid. Glukokortikoid kemudian akan merangsang kortisol dan katekolamin terutama epinefrin dan norefinefrin. Epinefrin dan norepinefrin mempunyai efek pada sel natural killer (NK) dan penurunan regulasi interferon (IFN) yang juga memberikan pengaruh terhadap pergeseran $\mathrm{T}$-helper cell atau T-h (suatu tipe sel darah putih atau leukosit). Pergeseran Th-1 ke Th-2 selama stres dapat meningkatkan respon hormonal terhadap alergen yang mengakibatkan obtruksi jalan nafas atau kekambuhan serangan asma (Surjanto, Sutanto, dan Duyen, 2013; Wardhana, 2010). Selain itu stres dapat mengganggu pengaturan sistem Hypothalamic-Pituitary-Adrenal (HPA). Stres akan menginduksi suatu keadaan hiporesponsif aksis HPA yang membuat sekresi kortisol berkurang dan terjadi peningkatan sekresi sitokin inflamasi. Kortisol mempunyai efek menghambat pada sistem imun. Stres menyebabkan perubahan aktivitas HPA yang dapat memperburuk kondisi individu yang mengalami asma, karena paparan terhadap kortisol dosis tinggi dapat membuat respon berlebihan Th-2 sitokin, yang dapat memicu kekambuhan asma (Surjanto, Sutanto, dan Duyen, 2013).

Berdasarkan uraian di atas dapat dilihat bahwa dampak psikologis yang ditimbulkan oleh asma dapat memperburuk kendisi individu yang mengalami asma. 
Dibutuhkan adanya penerimaan diri bagi individu yang mengalami asma untuk meminimalisir dampak psikologis yang dapat menjadi pemicu meningkatnya kekambuhan asma. Individu yang memiliki penerimaan diri akan lebih mampu menyesuaikan kondisi emosional dengan realitas yang dihadapi, memiliki keyakinan terhadap kemampuan yang dimiliki, memandang diri sebagai individu yang berharga, bertanggung jawab, berpendirian, serta mampu menerima kelebihan dan keterbatasan yang dimiliki (Anastri, 2011; Salwa \& dkk., 2010). Hurlock (dalam Tentama, 2010) menyatakan bahwa penerimaan diri adalah suatu kesadaran individu tentang karakteristik diri dan kemauan untuk hidup dengan keadaan dirinya. Ketika individu dapat menerima diri akan terbentuk sikap positif terhadap suatu keadaan yang tidak menyenangkan, sehingga individu mampu melihat keadaan yang dialami secara rasional, tidak mudah putus asa atau menghindar dari keadaan yang tidak menyenangkan tetapi akan mencari jalan keluar atas permasalahan yang dihadapi. Dengan demikian individu akan mempunyai mental yang kuat, yang akan membantu dalam menghadapi stresor kehidupan (Chaeruni dalam Dwitantyanov, 2012; Rizkiana \& Retnaningsih, 2009). Nurviana, Siswati dan Dewi (2009) juga mengungkapkan bahwa individu yang mengalami sakit kronis apabila memiliki penerimaan diri akan lebih tenang dalam menghadapi suatu permasalahan, mampu beradaptasi terhadap stres, beban yang dialami dapat menjadi lebih ringan serta kekambuhan penyakit yang dialami dapat menurun.

Pernyataan tersebut didukung oleh penelitian yang dilakukan oleh Novvida dan Syifa'a (2007) yaitu meneliti tentang penerimaan diri dan stres pada individu yang mengalami diabetes mellitus. Penelitian yang dilakukan menunjukkan hasil bahwa terdapat hubungan antara penerimaan diri dengan stres yang dialami oleh individu yang mengalami diabetes mellitus. Semakin individu dapat menerima diri maka stres yang dialami individu akan semakin rendah dan ketika penerimaan diri individu rendah, maka stres yang dialami individu akan semakin tinggi. Lebih lanjut penelitian tersebut menjelaskan bahwa stres muncul tergantung dari penerimaan diri individu. Individu yang rendah diri, tidak berpuas hati dengan diri, dan tidak menerima diri apa adanya akan membuat individu tidak akan merasa sejahtera dengan keadaan dirinya.

Mental yang sehat tidak hanya dapat terwujud dengan adanya penerimaan diri tetapi juga adanya dukungan sosial dari keluarga karena individu yang memperoleh dukungan sosial yang tinggi akan menjadi individu yang lebih optimis dan lebih mampu beradaptasi terhadap stres (Mazbow, 2009). Folonsen dan Beehr (dalam Komalasari, 2006) juga mengungkapkan bahwa dukungan sosial dapat secara efektif mengurangi stres yang dialami individu terlebih lagi pada individu yang mengalami sakit kronis, salah satunya adalah asma. Individu yang mengalami asma cenderung merasa diri tidak berdaya, cemas, stres, dan mengalami masalah finansial. Sheridan dan Radmacker (dalam Komalasari, 2006) menyebutkan bahwa adanya dukungan sosial dapat membuat individu menyadari bahwa ada lingkungan terdekat individu yaitu keluarga yang siap membantu individu dalam menghadapi tekanan. Dukungan sosial yang diberikan oleh keluarga dapat berupa dukungan emosional, dukungan penghargaan, dukungan alat, dan dukungan informatif (Adicondro \& Purnamasari, 2011).

Dukungan emosional yang diberikan oleh keluarga seperti rasa empati, selalu ada mendampingi individu ketika mengalami permasalahan, dan keluarga menyediakan suasana yang hangat di keluarga dapat membuat individu merasa diperhatikan, nyaman, diperdulikan dan dicintai oleh keluarga sehingga individu akan lebih mampu menghadapi masalah dengan lebih baik. Begitu juga dengan dukungan penghargaan yang diberikan oleh keluarga yang dapat berupa pemberian apresiasi ketika individu mencapai suatu keberhasilan, pemberian semangat, persetujuan pada pendapat individu dan perbandingan yang positif dengan individu lain. Dukungan ini membantu individu dalam membangun harga diri dan kompetensi. Dukungan penghargaan sangat dibutuhkan oleh individu yang mengalami asma karena berbagai dampak yang ditimbulkan oleh asma cenderung dapat membuat rasa percaya diri individu yang mengalami asma menurun. Adanya penghargaan yang positif dari keluarga akan membantu individu untuk meningkatkan rasa percaya dirinya (Sari, 2011; Johnson \& Johnson dalam Ermayanti \& Abdullah, 2011).

Selain dukungan emosional dan penghargaan, dukungan alat atau instrumental dari anggota keluarga juga sangat dibutuhkan oleh individu yang mengalami asma seperti pinjaman uang, pemberian barang, makanan serta pelayanan. Bentuk dukungan ini dapat mengurangi kecemasan karena individu dapat langsung memecahkan masalah yang berhubungan dengan materi. Dengan berkurangnya permasalahan yang dihadapi, stres yang dialami oleh individu yang mengalami asma dapat menurun (Sari, 2011; Cutetomatto, 2012). Tidak hanya perhatian ataupun bantuan berupa biaya pengobatan, dukungan informatif seperti masukan, saran, pemberian informasi pengobatan, pengetahuan, petunjuk, atau umpan balik tentang situasi dan kondisi individu juga sangat dibutuhkan oleh individu yang mengalami asma dalam mengatasi permasalahan yang dihadapi. Adanya dukungan informatif akan membuat wawasan individu menjadi lebih luas sehingga dapat lebih berpikir positif dalam menghadapi suatu permasalahan (Sari, 2011).

Johnson dan Johnson (dalam Ermayanti \& Abdullah, 2011) juga mengemukakan bahwa dukungan sosial adalah suatu usaha pemberian bantuan kepada individu dengan tujuan untuk meningkatkan kualitas kesehatan mental, meningkatkan rasa percaya diri, doa, semangat atau dorongan, 
nasihat serta sebuah penerimaan. Berbagai manfaat dari dukungan sosial keluarga dapat membantu individu yang mengalami asma menjadi individu yang mampu beradaptasi terhadap stres, dapat menyesuaikan diri dengan lingkungan dan mempunyai pemikiran yang lebih optimis. Selain itu, adanya dukungan sosial keluarga juga menjadi penunjang keberhasilan perawatan di rumah sakit bagi individu yang mengalami asma seperti peran keluarga yang turut serta membantu pihak rumah sakit saat pemberian obat kepada anggota keluarga yang mengalami asma (Ambari, 2010).

Pemaparan di atas diperkuat dengan hasil penelitian yang dilakukan oleh Komalasari (2006) yaitu dukungan sosial yang diterima oleh individu yang mengalami sakit jantung dapat meringankan beban penderitaan individu, individu menjadi lebih kuat dalam memerangi penyakit sehingga dapat menjalani hidup dengan lebih baik, sehat dan normal. Adanya dukungan emosional yang diterima individu berupa perhatian dapat membantu memulihkan kondisi individu menjadi lebih baik dan stres individu dapat menurun.

Berdasarkan uraian di atas dapat dilihat pentingnya penerimaan diri pada individu yang mengalami asma untuk mengurangi intensitas kekambuhan asma yang disebabkan oleh faktor psikologis dan juga peran dukungan sosial keluarga yang secara efektif mengurangi stres, maka peneliti tertarik untuk meneliti hubungan antara dukungan sosial keluarga dengan penerimaan diri individu yang mengalami asma.

\section{METODE}

\section{Variabel dan definisi operasional}

Variabel adalah suatu atribut atau objek yang ditetapkan oleh peneliti untuk dipelajari dan ditarik kesimpulannya (Sugiyono, 2011). Variabel yang digunakan dalam penelitian ini ada dua yaitu variabel bebas dan variabel tergantung. Variabel bebas atau juga disebut sebagai independent variable adalah variabel yang mempengaruhi perubahan pada variabel tergantung. Pada penelitian ini yang menjadi variabel bebas adalah dukungan sosial keluarga. Sedangkan variabel tergantung atau dependent variable adalah variabel yang dipengaruhi atau menjadi akibat karena adanya variabel bebas. Variabel tergantung pada penelitian ini adalah penerimaan diri. Definisi operasional dukungan sosial keluarga dan penerimaan diri adalah sebagai berikut:

1. Dukungan sosial keluarga adalah bantuan yang diterima oleh individu yang mengalami asma dari anggota keluarga individu yang mengalami asma yang dapat berupa dukungan emosional, dukungan penghargaan, dukungan alat, dan dukungan informatif. Dukungan sosial keluarga akan diukur dengan kuesioner yang disusun sendiri oleh peneliti menggunakan skala Likert berdasarkan aspek-aspek dukungan sosial menurut Johnson dan Johnson yaitu dukungan emosional, dukungan penghargaan, dukungan alat, dan dukungan informatif (dalam Ermayanti \& Abdullah, 2011).

2. Penerimaan diri adalah sikap yang pada dasarnya individu puas dengan diri sendiri dan menerima karakteristik diri yang tampak dari individu mempunyai perasaan sederajat dengan individu lain, percaya dengan kemampuan diri, bertanggung jawab, berorientasi keluar diri, berpendirian, menyadari keterbatasan, dan menerima sifat kemanusiaan. Penerimaan diri diukur dengan kuesioner yang disusun sendiri oleh peneliti menggunakan skala Likert berdasarkan aspekaspek penerimaan diri menurut Sheerer yaitu perasaan sederajat dengan individu lain, percaya dengan kemampuan diri, bertanggung jawab, berorientasi keluar diri, berpendirian, menyadari keterbatasan, dan menerima sifat kemanusiaan (dalam Dina, 2010).

\section{Responden}

Populasi adalah wilayah generalisasi yang terdiri atas subjek yang mempunyai kuantitas dan karakteristik tertentu yang ditetapkan oleh peneliti untuk dipelajari dan kemudian ditarik kesimpulannya (Sugiyono, 2011). Populasi pada penelitian ini adalah keseluruhan individu yang mengalami asma di Rumah Sakit Umum Daerah Sanjiwani Gianyar. Sedangkan sampel adalah sebagian subjek yang diambil dari keseluruhan subjek yang diteliti dan dianggap mewakili seluruh populasi (Notoatmodjo, 2006). Sampel pada penelitian ini adalah individu yang mengalami asma di Rumah Sakit Umum Daerah Sanjiwani Gianyar yang dipilih dengan menggunakan teknik sistematik random sampling yang berjumlah 105 individu yang mengalami asma.

\section{Tempat Penelitian}

Penelitian ini dilaksanakan di Rumah Sakit Umum Daerah Sanjiwani Gianyar, Bali pada bulan Januari - Februari 2013.

\section{Alat ukur}

Alat ukur yang digunakan mengukur variabel yang diteliti pada penelitian ini adalah kuesioner. Ada dua buah kuesioner yang digunakan yaitu kuesioner dukungan sosial keluarga dan kuesioner penerimaan diri. Kuesioner dukungan sosial keluarga disusun berdasarkan aspek dukungan sosial keluarga menurut Johnson dan Johnson (dalam Ermayanti \& Abdullah, 2011). Sedangkan kuesioner penerimaan diri disusun berdasarkan aspek-aspek penerimaan diri menurut Sheerer (dalam Dina, 2010). Kedua kuesioner disusun sendiri oleh peneliti menggunakan skala Likert dengan empat alternatif jawaban yaitu "sangat setuju", "setuju", "tidak setuju", dan "sangat tidak setuju". 
Kuesioner dukungan sosial keluarga dan kuesioner penerimaan diri dilakukan uji coba terlebih dahulu sebelum diberikan kepada sampel yang sebenarnya untuk melihat validitas dan reliabilitas kuesioner. Uji coba tidak terpakai dilakukan pada 60 individu yang mengalami asma di Rumah Sakit Umum Daerah Klungkung. Uji validitas dan reliabilitas kuesioner pada penelitian ini menggunakan Alpha Cronbach dengan bantuan SPSS 17.0. Validitas kuesioner dinyatakan memiliki validitas yang baik apabila memiliki nilai $r$ lebih besar dari 0,30. Sedangkan kuesioner dinyatakan memiliki reliabilitas yang baik apabila memiliki nilai koefisien alpha lebih besar dari 0,60.

Berdasarkan uji coba alat ukur yang dilakukan, diperoleh hasil bahwa terdapat 5 pernyataan yang gugur dari 30 pernyataan sehingga pernyataan yang valid pada kuesioner dukungan sosial keluarga berjumlah 27 pernyataan. Sedangkan pada kuesioner penerimaan diri terdapat 12 pernyataan yang gugur dari 42 pernyataan sehingga pernyataan yang valid pada kuesioner penerimaan diri berjumlah 30 pernyataan. Uji coba alat ukur yang dilakukan juga menunjukkan bahwa koefisien reliabilitas kuesioner dukungan sosial keluarga sebesar 0,896 dan koefisien reliabilitas kuesioner penerimaan diri adalah sebesar 0,899.

\section{Metode pengumpulan data}

Pengumpulan data pada penelitian ini dilakukan dengan cara melakukan pengukuran terhadap dua variabel yang diteliti yaitu dukungan sosial keluarga dan penerimaan diri individu yang mengalami asma. Skala pengukuran kedua variabel menggunakan kuesioner. Kuesioner yang sudah disusun sendiri oleh peneliti dan telah teruji validitas dan reliabilitasnya, disebar kepada subjek penelitian yaitu individu yang mengalami asma di Rumah Sakit Umum Daerah Sanjiwani Gianyar. Kuesioner mencantumkan inisial nama subjek, usia, jenis kelamin, alamat dan pengarahan mengenai cara menjawab kuesioner. Subjek diwajibkan untuk memilih salah satu dari empat alternatif jawaban dengan sebelumnya diingatkan bahwa tidak ada jawaban yang benar atau salah. Peneliti juga menjelaskan bahwa identitas subjek penelitian akan dijaga kerahasiaannya. Hal tersebut tercantum dalam surat permohonan untuk menjadi subjek penelitian. Setelah data terkumpul, data kemudian dianalisis menggunakan bantuan SPSS 17.0.

\section{Teknik Analisis Data}

Metode analisis data adalah cara untuk mengolah, menganalisa data dan menguji kebenaran, kemudian dapat disimpulkan hasil dari penelitian tersebut. Metode analisis data pada penelitian ini menggunakan pendekatan kuantitatif dengan metode korelasional. Metode korelasi yang digunakan yaitu korelasi Pearson Product Moment. Korelasi Pearson Product Moment merupakan suatu teknik korelasi yang digunakan untuk melihat hubungan dan membuktikan hipotesis hubungan dua variabel apabila data kedua variabel berbentuk interval dan sumber data dari dua variabel adalah sama (Sugiyono, 2011). Analisis data pada penelitian ini menggunakan bantuan SPSS 17.0.

\section{HASIL PENELITIAN}

Metode analisis data yang digunakan pada penelitian ini adalah menggunakan uji Pearson Product Moment. Namun sebelum melakukan analisis Pearson Product Moment, ada dua persyaratan yang harus terpenuhi yaitu data bersifat normal dan linear (Usman \& Akbar, 2011). Pada penelitian ini, uji normalitas dilakukan dengan menggunakan Kolmogorov-Smirnov dengan bantuan SPSS 17.0. Data dinyatakan berdistribusi normal apabila nilai signifikansi data lebih besar dari 0,05 (Priyatno, 2008). Hasil uji normalitas tergambar pada Tabel 1.

Tabel 1

Hasil Uji Normalitas

\begin{tabular}{ccc}
\hline & $\begin{array}{c}\text { Dukungan Sosial } \\
\text { Keluarga }\end{array}$ & Penerimaan Diri \\
\hline $\begin{array}{c}\text { Kolmogorov- } \\
\text { Smirnov Z }\end{array}$ & 0,642 & 0,685 \\
\hline Asymp. Significant & 0,805 & 0,737 \\
\hline
\end{tabular}

Berdasarkan uji normalitas yang dilakukan diperoleh hasil bahwa nilai signifikansi variabel dukungan sosial keluarga memiliki nilai signifikansi sebesar 0,805 sedangkan variabel penerimaan diri memiliki nilai signifikansi sebesar 0,737. Kedua variabel memiliki nilai signifikansi lebih besar dari 0,05 yang menunjukkan bahwa data variabel dukungan sosial keluarga dan variabel penerimaan diri bersifat normal.

Selain uji normalitas, penelitian ini juga melakukan uji linearitas. Uji linearitas dilakukan dengan menggunakan compare mean dengan bantuan SPSS 17.0. Kedua variabel memiliki hubungan yang linear apabila memiliki nilai signifikansi yang lebih kecil dari 0,05 (Boediono \& Koster, 2004). Berdasarkan uji linearitas yang dilakukan diperoleh hasil bahwa hubungan antara dukungan sosial keluarga dengan penerimaan diri adalah linear. Hal ini terlihat dari taraf signifikansi lebih kecil dari 0,05 yaitu sebesar 0,000. Berdasarkan hasil tersebut dapat dikatakan bahwa pola atau arah hubungan antara dukungan sosial keluarga dengan penerimaan diri adalah linear atau searah. Hasil uji linearitas tergambar pada Tabel 2.

\begin{tabular}{ccccc}
\multicolumn{5}{c}{ Tabel 2 } \\
& Hasil Uji Linearitas \\
\hline & & & $\mathrm{F}$ & Signifikansi \\
\hline Penerimaan Diri* & Between & Combined & 5,284 & 0,000 \\
\cline { 3 - 5 } Dukungan Sosial & Groups & Linearity & 117,863 & 0,000 \\
\cline { 3 - 5 } & & $\begin{array}{c}\text { Deviation from } \\
\text { Linearity }\end{array}$ & 1,873 & 0,014 \\
& & &
\end{tabular}

Setelah diperoleh hasil kedua data bersifat normal dan linear, maka dilakukan uji hipotesis. Pengujian hipotesis 
dilaksanakan untuk membuktikan hipotesis yang diajukan dalam sebuah penelitian akan diterima atau ditolak. Hipotesis dalam penelitian ini terdiri atas hipotesis nol (Ho) dan hipotesis alternatif $(\mathrm{Ha})$. Hipotesis nol pada penelitian ini berbunyi tidak ada hubungan antara dukungan sosial keluarga dengan penerimaan diri individu yang mengalami asma. Sedangkan hipotesis alternatif pada penelitian ini berbunyi ada hubungan antara dukungan sosial keluarga dengan penerimaan diri individu yang mengalami asma. Uji hipotesis yang digunakan yaitu uji Pearson Product Moment dengan bantuan SPSS 17.0. Hasil uji hipotesis tergambar pada Tabel 3.

Tabel 3

\begin{tabular}{llcc}
\multicolumn{4}{c}{ Hasil Pengujian Hipotesis } \\
\hline & \multicolumn{1}{c}{$\begin{array}{c}\text { Dukungan Sosial } \\
\text { Keluarga }\end{array}$} & Penerimaan Diri \\
\hline \multirow{2}{*}{ Dukungan Sosial Keluarga } & Pearson Correlation & 1 & 0,687 \\
\cline { 2 - 4 } & Sig. (2-tailed) & 105 & 0,000 \\
\cline { 2 - 4 } & $\mathrm{N}$ & 0,687 & 105 \\
\hline Penerimann Diri & Pearson Correlation & 0,000 & 1 \\
\cline { 2 - 4 } & Sig. (2-tailed) & 105 & 105 \\
\cline { 2 - 3 } & $\mathrm{N}$ & & \\
\hline
\end{tabular}

Berdasarkan pengujian hipotesis menggunakan Pearson Product Moment, diperoleh hasil nilai pearson correlation (r) sebesar 0,687 dengan taraf signifikansi 0,000. Hal ini menunjukkan bahwa hipotesis nol (Ho) pada penelitian ini ditolak karena nilai signifikansi lebih kecil dari 0,05 ( $\mathrm{p}<$ 0,05) dan hipotesis alternatif (Ha) diterima. Maka dapat dinyatakan bahwa ada hubungan antara dukungan sosial keluarga dengan penerimaan diri individu yang mengalami asma.

Nilai korelasi yang positif pada nilai $\mathrm{r}$ sebesar 0,687 menunjukkan bahwa ada hubungan positif dan searah antara dukungan sosial keluarga dengan penerimaan diri. Ketika nilai subjek pada variabel dukungan sosial keluarga meningkat, maka nilai subjek pada variabel penerimaan diri juga terjadi peningkatan. Begitu pula sebaliknya ketika nilai subjek pada variabel dukungan sosial menurun, maka nilai subjek pada variabel penerimaan diri juga mengalami penurunan.

Besar kontribusi dukungan sosial keluarga terhadap penerimaan diri dapat dilihat dari nilai determinasi (r2). Pada penelitian ini, koefisien determinasi sebesar 0,4720. Hal ini menunjukkan bahwa dukungan sosial keluarga dapat menjelaskan penerimaan diri sebesar $47,20 \%$, sisanya $52,80 \%$ dijelaskan oleh faktor lain yang tidak diteliti pada penelitian ini.

Selain dapat menggambarkan hubungan antara dukungan sosial keluarga dengan penerimaan diri individu yang mengalami asma, hasil dari penelitian ini juga menunjukkan nilai maksimum subjek pada variabel dukungan sosial keluarga yaitu 97 dan nilai minimumnya adalah 58 . Nilai rata-rata subjek pada variabel dukungan sosial keluarga yaitu 77,73 dengan standar deviasi sebesar 8,700. Sedangkan nilai maksimum subjek pada variabel penerimaan diri yaitu 107 dan nilai minimumnya adalah 62. Nilai rata-rata subjek pada variabel penerimaan diri yaitu 84,98 dengan standar deviasi 9,922.

Berdasarkan nilai yang diperoleh subjek pada masing-masing variabel, maka subjek dapat digolongkan ke dalam beberapa kategori untuk memperoleh gambaran subjek penelitian pada variabel yang diteliti. Menurut Azwar (2010), kategorisasi skor memberi gambaran penting mengenai distribusi skor skala pada kelompok subjek yang dikenai pengukuran dan berfungsi sebagai sumber informasi mengenai keadaan subjek pada variabel yang diteliti. Penelitian ini menggunakan kategorisasi jenjang yang digolongkan menjadi lima kategori yaitu sangat rendah, rendah, sedang, tinggi, dan sangat tinggi dengan rumus yang digambarkan pada Tabel 4.

Tabel 4

Rumus Kategorisasi Skor

\begin{tabular}{cc}
\hline Skor & Kategorisasi \\
\hline $\mathrm{X} \leq(\mu-1,5 \sigma)$ & Sangat Rendah \\
\hline$(\mu-1,5 \sigma)<\mathrm{X} \leq(\mu-0,5 \sigma)$ & Rendah \\
\hline$(\mu-0,5 \sigma)<\mathrm{X} \leq(\mu+0,5 \sigma)$ & Sedang \\
\hline$(\mu+0,5 \sigma)<\mathrm{X} \leq(\mu+1,5 \sigma)$ & Tinggi \\
\hline$(\mu+1,5 \sigma)<\mathrm{X}$ & Sangat Tinggi \\
\hline
\end{tabular}

Keterangan :

$\mathrm{X}$ : Skor subjek

$\mu$ : Rata-rata skor total

$\sigma:$ SD dari skor total

Kategorisasi jenjang seperti yang digambarkan pada Tabel 4, dapat menempatkan subjek ke dalam lima kategori berdasarkan skor yang diperoleh pada masing-masing variabel yaitu dukungan sosial keluarga dan penerimaan diri seperti yang tergambar pada Tabel 5 dan Tabel 6.

Tabel 5

Kategorisasi Skor Dukungan Sosial Keluarga

\begin{tabular}{|c|c|c|c|}
\hline Skor & Kategorisasi & Jumlah & Persentase \\
\hline $\mathrm{X} \leq 64,68$ & Sangat Rendah & 9 & $8,57 \%$ \\
\hline $64,68<\mathrm{X} \leq 73,38$ & Rendah & 24 & $22,86 \%$ \\
\hline $73,38<X \leq 82,08$ & Sedang & 41 & $39,05 \%$ \\
\hline $82,08<X \leq 90,78$ & Tinggi & 25 & $23,81 \%$ \\
\hline $90,78<X$ & Sangat Tinggi & 6 & $5,71 \%$ \\
\hline
\end{tabular}

Berdasarkan Tabel 5, dapat dilihat bahwa sebanyak 9 subjek atau $8,57 \%$ subjek memiliki skor dukungan sosial yang tergolong sangat rendah, 24 subjek atau 22,86\% subjek memiliki skor dukungan sosial yang tergolong rendah, 41 subjek atau 39,05\% subjek memiliki nilai dukungan sosial yang tergolong sedang, 25 subjek atau 23,81\% subjek memiliki skor dukungan sosial yang tergolong tinggi, dan sebanyak 6 subjek atau 5,71\% subjek memiliki skor dukungan sosial yang tergolong sangat tinggi.

Tabel 6

Kategorisasi Skor Penerimaan Diri

\begin{tabular}{cccc}
\multicolumn{4}{c}{ Kategorisasi Skor Penerimaan Diri } \\
\hline Skor & Kategorisasi & Jumlah & Persentase \\
\hline $\mathrm{X} \leq 70,10$ & Sangat Rendah & 8 & $7,62 \%$ \\
\hline $70,10<\mathrm{X} \leq 80,02$ & Rendah & 27 & $25,71 \%$ \\
\hline $80,02<\mathrm{X} \leq 89,94$ & Sedang & 31 & $29,52 \%$ \\
\hline $89,94<\mathrm{X} \leq 99,86$ & Tinggi & 35 & $33,33 \%$ \\
\hline $99,86<\mathrm{X}$ & Sangat Tinggi & 4 & $3,81 \%$ \\
\hline
\end{tabular}

Berdasarkan data yang diperoleh seperti yang tergambar pada Tabel 6, dapat dilihat bahwa sebagian besar nilai penerimaan diri subjek termasuk dalam kategori tinggi yaitu sebanyak 35 subjek atau 33,33\%. Sebanyak 4 subjek 
atau $3,81 \%$ subjek memiliki skor penerimaan diri yang tergolong sangat tinggi, 31 subjek atau 29,52\% subjek memiliki skor penerimaan diri yang tergolong sedang, sebanyak 27 subjek atau $25,71 \%$ subjek memiliki skor penerimaan diri yang tergolong rendah, dan sebanyak 8 subjek atau $7,62 \%$ subjek memiliki skor penerimaan diri yang tergolong sangat rendah.

\section{PEMBAHASAN DAN KESIMPULAN}

Hasil pengujian hipotesis menggunakan uji Pearson Product Moment menunjukkan hasil nilai $\mathrm{r}$ sebesar 0,687 dengan nilai signifikansi sebesar 0,000. Nilai signifikansi 0,000 lebih kecil dari 0,05 sehingga hipotesis nol (Ho) pada penelitian ini ditolak dan hipotesis alternatif (Ha) diterima yang menunjukkan bahwa terdapat hubungan antara dukungan sosial keluarga dengan penerimaan diri individu yang mengalami asma.

Asma merupakan sakit kronis menahun yang tidak dapat disembuhkan. Berbagai perubahan pada fisik, psikologis, maupun pola hidup individu yang mengalami asma mengalami perubahan (Ayres, 2003). Kehadiran orang terdekat yaitu keluarga sangat dibutuhkan untuk memberikan dukungan. Keluarga merupakan tempat individu bercerita dan mengeluarkan keluhan-keluhan apabila individu mengalami suatu permasalahan. Individu cenderung menganggap bahwa keluarga merupakan tempat yang paling nyaman untuk berbagi dalam menghadapi segala persoalan hidup, berbagi kebahagiaan dan tempat tumbuhnya harapan-harapan hidup yang lebih baik. Melalui dukungan sosial keluarga, kesejahteraan psikologis akan meningkat karena adanya perhatian dan pengertian yang akan menimbulkan perasaan memiliki, meningkatkan harga diri dan kejelasan identitas diri serta memiliki perasaan positif mengenai diri sendiri (Irwanto dalam Pangastiti, 2011).

Selain adanya dukungan sosial keluarga, individu yang mengalami asma juga harus memiliki penerimaan diri. Individu yang dapat menerima diri adalah individu yang memiliki perasaan sederajat, percaya dengan kemampuan diri, bertanggung jawab, memiliki orientasi keluar diri, berpendirian, menyadari keterbatasan-keterbatasannya, dan menerima sifat kemanusiaan (Sheerer dalam Dina, 2010). Penerimaan diri dapat membuat individu dapat memandang diri lebih positif, stres yang dialami dapat menurun, dan individu juga menjadi lebih mudah dalam menyesuaikan diri secara emosional maupun penyesuaian diri dengan lingkungan (Hurlock, 2004). Dengan menurunnya stres yang dialami oleh individu, intensitas kekambuhan asma dapat berkurang. Hal tersebut dikarenakan stres dapat mempengaruhi sistem imum tubuh (Sarafino \& Smith. 2011). Ketika individu mengalami stres, maka sistem imun mempengaruhi kerja sistem Hipotalamic-Pituitry-Adrenal (HPA). Apabila HPA terangsang, maka terjadi peningkatan glukokortikoid.
Glukokortikoid merupakan hormon yang penting dalam regulasi sistem imun. Terjadinya peningkatan glukokortikoid mengakibatkan terjadi ketidakseimbangan sistem neuroendokrin (hormon) sehingga akan terjadi pergeseran Thelper cell (Th) yaitu pergeseran Th-1 ke Th-2. Pergeseran Th-1 ke Th-2 akan menyebabkan hipersensitivitas respon imun terhadap alergen sehingga akan memicu kekambuhan serangan asma (Wardhana, 2010). Berdasarkan uraian di atas dapat dilihat keterkaitan antara pentingnya dukungan sosial keluarga dan penerimaan diri pada individu yang mengalami asma.

Nilai korelasi yang positif pada nilai $r$ sebesar 0,687 menunjukkan bahwa terdapat hubungan yang positif atau searah antara dukungan sosial keluarga dengan penerimaan diri individu yang mengalami asma. Hubungan yang positif atau searah artinya ketika nilai pada variabel dukungan sosial keluarga meningkat, maka nilai pada variabel penerimaan diri juga meningkat. Bagitu juga sebaliknya, ketika nilai variabel dukungan sosial keluarga turun, maka nilai variabel penerimaan diri juga mengalami penurunan. Menurut Taylor (2003), dukungan yang dimiliki oleh individu dapat mencegah berkembangnya masalah akibat tekanan yang dihadapi. Individu yang memperoleh dukungan sosial lebih tinggi akan lebih berhasil mengatasi dan menghadapi masalah dibandingkan dengan individu yang tidak memperoleh dukungan atau memperoleh dukungan sosial yang tergolong rendah.

Dukungan sosial yang diberikan oleh keluarga dapat berupa dukungan emosional, dukungan penghargaan, dukungan instrumental atau alat, dan dukungan informatif. Setiap jenis dukungan memberikan pengaruh atau manfaat bagi individu yang menerimanya. Menurut Ermayanti dan Abdullah (2011), apabila individu memperoleh dukungan emosional yang tinggi, individu akan merasa mendapatkan dorongan yang tinggi dari anggota keluarga. Individu yang mengalami asma merasa bahwa anggota keluarga memberikan perhatian pribadi pada dirinya atas kerelaan anggota keluarga yang lain untuk membantu memecahkan atau mencari jalan keluar bagi permasalahan yang dihadapi. Dukungan emosional berkaitan dengan salah satu faktor yang mempengaruhi penerimaan diri individu yaitu tidak adanya gangguan emosional di dalam lingkungan. Dengan tidak adanya hambatan emosional dalam lingkungan, individu dapat lebih menerima dirinya. Dukungan emosional yang diberikan oleh keluarga membuat individu dapat bekerja lebih baik dan lebih bahagia. Terlebih lagi pada individu yang mengalami penyakit kronis, dukungan emosional yang diterima melalui perhatian dapat membantu memulihkan kondisi individu yang mengalami penyakit kronis menjadi lebih baik, individu merasa senang dan tingkat stres individu dapat menurun (Komalasari, 2010). 
Bentuk lain dari dukungan sosial yang dapat diberikan keluarga yaitu dukungan penghargaan. Apabila penghargaan untuk individu tersebut besar, maka akan meningkatkan kepercayaan diri individu (Ermayanti \& Abdullah, 2011; Nurmalasari, 2007). Kepercayaan diri adalah salah satu sikap individu yang tampak ketika individu dapat menerima diri yaitu individu percaya dengan kemampuan yang dimilikinya. Menurut Sheerer dalam Dina (2010), individu yang percaya diri akan lebih suka mengembangkan sikap baiknya dan mengeliminasi keburukannya dari pada ingin menjadi individu lain, oleh karena itu individu puas menjadi diri sendiri. Ketika individu yang mengalami asma puas dengan dirinya, individu akan mampu mengoptimalkan potensi-potensi yang dimiliki dan tidak hanya terus memikirkan dan menyesali penyakit yang dialami. Individu yang percaya dengan kemampuan diri lebih mampu bangkit dari keterpurukan dan tingkat stres yang dialami dapat menurun.

Dukungan instrumental juga merupakan salah satu bentuk dukungan yang diberikan keluarga kepada anggota keluarga yang mengalami asma. Individu yang memperoleh dukungan instrumental akan merasa dirinya mendapat fasilitas yang memadai dari keluarga. Dukungan instrumental atau alat berupa bantuan yang bersifat langsung seperti pemberian peralatan, uang, pekerjaan yang dibutuhkan (Ermayanti \& Abdullah, 2011). Hal tersebut dapat mempermudah individu mencapai tujuan yang ingin dicapainya. Ketika individu mampu memperoleh keberhasilan baik secara kuantitatif maupun kualitatif, maka dapat meningkatkan penerimaan diri dan sebaliknya kegagalan individu dalam mencapai tujuannya akan mengakibatkan turunnya penerimaan diri atau dapat mengakibatkan penolakan diri. Individu yang mengalami asma sangat membutuhkan dukungan alat atau instrumental dari anggota keluarga untuk mencapai tujuan-tujuannya seperti menjalani suatu pengobatan. Dukungan berupa uang dapat membantu individu yang mengalami asma dalam mengatasi masalah finansial karena harus menjalani pengobatan secara rutin. Selain itu penyediaan alat penunjang kesehatan seperti obat-obatan dan membantu menyediakan lingkungan yang nyaman bagi individu yang mengalami asma juga dapat mengurangi intensitas kekambuhan asma.

Keberhasilan individu dalam mencapai tujuan tidak hanya dapat terwujud dari dukungan instrumental melainkan juga adanya dukungan informatif dari anggota keluarga. Menurut (Ermayanti \& Abdullah, 2011), Apabila individu memperoleh dukungan informatif, individu akan merasa memperoleh perhatian dan pengetahuan. Pengetahuan dan pengalaman yang dimiliki oleh individu dapat mengembangkan perspektif diri yang luas yang akan mempengaruhi penerimaan diri individu terkait dengan cara individu memandang dirinya.
Besar kontribusi dukungan sosial keluarga terhadap penerimaan diri individu yang mengalami asma pada penelitian ini dapat dilihat dari nilai determinasi (r2) yang diperoleh berdasarkan analisis yang dilakukan. Koefisien determinasi pada penelitian ini sebesar 0,4720. Hal ini menunjukkan bahwa dukungan sosial keluarga dapat menjelaskan penerimaan diri sebesar $47,20 \%$, sisanya $52,80 \%$ dijelaskan oleh faktor lain yang tidak diteliti pada penelitian ini seperti dukungan sosial teman sebaya, kemampuan individu untuk berpikir positif, pola asuh dimasa kecil dan sebagainya (Dina, 2010; Tentama, 2010; Nurviana, Siswati \& Dewi, 2012).

Berdasarkan ketegorisasi skor subjek, diperoleh hasil bahwa sebagian besar subjek memperoleh dukungan sosial keluarga pada rentang sedang hingga tinggi. Hal ini menunjukkan bahwa dukungan sosial keluarga merupakan salah satu faktor penting yang dibutuhkan oleh individu yang mengalami asma, dalam bentuk dukungan emosional, dukungan penghargaan, dukungan alat, dan dukungan informatif. Selain itu, kategorisasi skor subjek juga menunjukkan bahwa sebagian besar subjek memiliki penerimaan diri pada rentang sedang hingga tinggi. Hal tersebut mendukung hasil penelitian yang menunjukkan bahwa terdapat hubungan antara dukungan sosial keluarga dengan penerimaan diri individu yang mengalami asma. Ketika individu yang mengalami asma memperoleh dukungan sosial keluarga yang tergolong tinggi, maka penerimaan diri individu yang mengalami asma juga menunjukkan skor yang tergolong tinggi.

Jadi dapat disimpulkan bahwa terdapat hubungan yang positif antara dukungan sosial keluarga dengan penerimaan diri individu yang mengalami asma. Hal tersebut menunjukkan bahwa semakin tinggi dukungan sosial keluarga maka semakin tinggi penerimaan diri individu yang mengalami asma. Hasil penelitian yang memperoleh hasil nilai koefisien korelasi sebesar 0,687 dengan koefisien determinasi sebesar 0,4720 menunjukkan bahwa dukungan sosial keluarga dapat menjelaskan penerimaan diri individu yang mengalami asma sebesar 47,20\% sedangkan 52,80\% dijelaskan oleh faktor lain yang tidak diteliti pada penelitian ini.

Sebagian besar subjek memiliki rata-rata skor dukungan sosial keluarga pada rentang sedang hingga tinggi yaitu sebanyak 41 subjek atau 39,05\% subjek memiliki dukungan sosial keluarga yang tergolong sedang, dan sebanyak 25 subjek atau 23,81\% subjek memiliki dukungan sosial keluarga yang tergolong tinggi. Begitu juga dengan penerimaan diri subjek sebagian besar berada pada rentang penerimaan diri sedang hingga tinggi yaitu sebanyak 31 subjek atau 29,52\% subjek memiliki penerimaan diri yang tergolong sedang, dan sebanyak 35 subjek atau 33,33\% subjek memiliki penerimaan diri yang tergolong tinggi. 
Berdasarkan hasil penelitian yang diperoleh dapat diberikan saran kepada individu yang mengalami asma, anggota keluarga dan pihak rumah sakit. Individu yang mengalami asma dapat meningkatkan penerimaan diri dengan cara memandang diri lebih positif, percaya dengan kemampuan diri, tidak hanya memikirkan penyakit yang dialami tetapi juga melakukan aktivitas-aktivitas sosial dan berinteraksi dengan lingkungan sosial seperti berinteraksi dengan keluarga. Individu yang mengalami asma dapat berbagi atau mengungkapkan keluhan-keluhan yang dialami kepada anggota keluarga yang lain sehingga masalah yang dihadapi dapat lebih ringan. Stres yang dialami oleh individu yang mengalami asma juga dapat lebih diminimalisir sehingga intensitas kekambuhan asma dapat menurun.

Saran yang dapat diberikan kepada keluarga yang memiliki anggota keluarga yang mengalami asma agar lebih memberikan dukungan sosial baik berupa dukungan emosional, dukungan penghargaan, dukungan instrumental, maupun dukungan informatif. Dukungan emosional yang diberikan dapat dilakukan dengan memberikan cinta dan kasih sayang, menunjukkan kepedulian dan perhatian, memberikan semangat, serta membantu memecahkan masalah yang dihadapi oleh anggota keluarga yang mengalami asma. Dukungan penghargaan yang dapat diberikan oleh keluarga seperti memberikan penghargaan atau apresiasi ketika anggota keluarga yang mengalami asma tersebut mencapai suatu prestasi, dan memberikan dorongan untuk terus berkreativitas. Dukungan lainnya yaitu dukungan instrumental atau alat seperti memberikan uang, membiayai pengobatan, membantu menyediakan peralatan yang dapat menunjang kesehatan anggota keluarga yang mengalami asma, serta menyediakan lapangan pekerjaan. Dukungan lain yang dapat diberikan yaitu dukungan informatif seperti membantu mencari informasi pengobatan penyakit asma, memberikan nasihat, saran atau pemecahan masalah terhadap masalah yang dihadapi oleh anggota keluarga yang mengalami asma. Adanya dukungan sosial keluarga akan membantu individu untuk mencapai penerimaan diri sehingga kualitas hidup individu yang mengalami asma menjadi lebih baik dan intensitas kekambuhan asma dapat berkurang.

Bagi pihak rumah sakit juga diharapkan dapat menjadikan dukungan sosial keluarga sebagai salah satu program tambahan atau alternatif untuk menunjang perawatan medis seperti pemberian obat. Dengan melibatkan keluarga dalam perawatan individu yang mengalami asma, maka individu yang mengalami asma akan merasa diperhatikan, dicintai, disayangi oleh banyak pihak yang kemudian dapat meningkatkan penerimaan diri individu yang mengalami asma. Dengan adanya penerimaan diri pada individu yang mengalami asma, maka stres yang dialami oleh individu dapat menurun sehingga kekambuhan asma yang dipicu oleh faktor psikologis dapat diminimalisir. Pihak rumah sakit dapat mengikutsertakan anggota keluarga individu yang mengalami asma dalam perawatan kesehatan individu yang mengalami asma seperti dalam program kepatuhan minum obat.

\section{DAFTAR PUSTAKA}

Adicondro, N., \& Purnamasari, A. (2011). Efikasi Diri, Dukungan Sosial Keluarga Dan Self Regulated Learning Pada Siswa Kelas VIII. Humanitas , 17-27.

Admin. (2012, Maret 4). Obat Alami Penyakit Asma. Retrieved Mei 12, 2012, from http://didinsaripudin.com/2012/03/obat-alamipenyakit-asma/

Ambari, P. K. (2010). Hubungan Antara Dukungan Keluarga Dengan Keberfungsian Sosial Pada Pasien Skizofrenia Pasca Perawatan Di Rumah Sakit. Skripsi. Semarang: Fakultas Psikologi Universitas Diponegoro.

Anastri, R. (2011). Self Acceptance In Adolescence Who Have Parent Polygamy. Artikel Psychology .

Ayres, J. (2003). Asma. Jakarta: Dian Rakyat

Azwar, S. (2010). Penyusunan Skala Psikologi. Yogyakarta: Pustaka Pelajar.

Azwar, S. (2010). Reliabilitas dan Validitas. Yogyakarta: Pustaka Pelajar.

Boediono, \& Koster, W. (2004). Teori dan Aplikasi Statistika dan Probabilitas. Bandung: PT Remaja Rosdakarya.

Cahyani, A. R. (2013, Februari 15). Asuhan Keperawatan Pada Klien Dengan Hypersensitivetas Pada Sistem Respirasi Asma. Retrieved Mei 5, 2013, from http://rifaaprilliafkp11.web.unair.ac.id/artikel_detail-72729-UmumASUHAN\%20 KEPERAWATAN\%20PADA\%20KLIEN\%20DENGAN\%20H YPERSENSITIVITAS\%20PADA\%20SISTEM\%20RESPIRAS I\%20ASMA.htm

Cutetomatto. (2012, November 22). Pengaruh Psikologi Pada Penderita Asma. Retrieved April 20, 2013, from Pengaruh Psikologi Pada Penderita Asma: http://artikelduniawanita.com/pengaruh-psikologi-padapenderita-asma.html

Davidson, G. C., Neale, J. M., \& Kring, A. M. (2006). Psikologi Abnormal. Jakarta: PT Raja Grafindo Persada.

Dina, Y. S.(2010). Hubungan Antara Penerimaan Diri dengan Kompetensi Interpersonal pada Remaja Panti Asuhan. Skripsi. Surakarta: Fakultas Psikologi Universitas Muhammadiyah Surakarta

Dwitantyanov, A. (2012, Mei 18). Stres. Retrieved Mei 5, 2013, from http://lelakiberjubahhitam.wordpress.com/2012/05/18/stres/ 
Ermayanti, S., \& Abdullah, S. M. (2011). Hubungan Antara Persepsi Terhadap Dukungan Sosial Dengan Penyesuaian Diri Pada Masa Pensiun .

Hurlock, E. B. (2004). Psikologi Perkembangan Suatu Pendekatan Sepanjang Rentang Kehidupan. In R. M. Sijabat (Ed.). Jakarta: Erlangga.

Komalasari, E. (2010). Dukungan Sosial Pada Penderita Sakit Jantung.

Mazbow. (2009, Agustus 09). Apa itu Dukungan Sosial? Retrieved September 25, 2012, from http://www.masbow.com/2009/08/apa-itu-dukungan-sosial.html

Meetdoctor. (2012). Asma. Retrieved Mei 5, 2013, from http://meetdoctor.com/topic/asma

Mjundi. (2012, May 8). Asma, dapat kita kontrol. Retrieved May 13, 2012, from http://lkc.eramuslim.com/wp/asma-dapat-kitakontrol/

Notoatmodjo, S. (2006). Metodologi Penelitian Kesehatan. Jakarta: Rineka Cipta.

Novvida, K., \& Syifa'a, R. (2007). Penerimaan Diri Dan Stres Pada Penderita Diabetes Millitus. Skripsi. Yogyakarta: Program Studi Psikologi Fakultas Psikologi Dan Sosial Budaya Universitas Islam Indonesia

Nurmalasari, Y. (2007). Hubungan Antara Dukungan Sosial Dengan Harga Diri Pada Remaja Penderita Penyakit Lupus.

Nurviana, E. V., Siswati, \& Dewi, K. S. (2012). Penerimaan Diri Pada Penderita epilepsi.

Pangastiti. K. N., (2011). Analisis Pengaruh Dukungan Sosial Keluarga Terhadap Burnout Pada Perawat Kesehatan Di Rumah Sakit Jiwa. Skripsi. Semarang: Universitas Diponegoro

Priyatno, D. (2008). Statistikal Product and Service Solution. Yogyakarta: CV ANDI.

Rizkiana, U., \& Retnaningsih. (2009). Penerimaan Diri Pada Remaja Penderita Leukemia. Jurnal Ilmiah Psikologi, 2.

Salwa, U., Kuncoro, J., \& Setyaningsih, R. (2010). Dukungan Sosial Keluarga dan Persepsi Terhadap Vonis dengan Penerimaan Diri Narapidana Lembaga Pemasyarakatan Klas II.A Wanita Semarang. Proyeksi, V (2), 79-89.

Sarafino, E. P., \& Smith, T. W. (2011). Health Psychology Biopsychological Interactions. Jhon Wiley \& Sons, Inc.

Sari, K. (2011, Februari 25). Konsep Dukungan Sosial . Retrieved Mei 2013, 5, from http://artidukungansosial.blogspot.com/
Sugiyono. (2011). Statistika untuk Penelitian. Bandung: Alfabeta.

Surjanto, E., Sutanto, Y. S., \& Duye, N. (2013). Peran Stres Pada Serangan Asma. Retrieved Mei 2013, 5, from http://fk.uns.ac.id/index.php/penelit - letail/32/peranstres-pada-serangan-asma

Taylor, S.E., (2003). Health Psychology. new y ork : McGraw Hill.

Tentama, F. (2010). Berpikir Positif Dan Penerimaan Diri Pada Remaja Penyandang Cacat Tubuh Akibat Kecelakaan. Humanitas, VII.

Usman., Akbar, S. (2011). Pengantar Statistika. Jakarta: PT. Bumi Aksara

Wahyudi, M. Z. (2012, Mei 8). Pencetus Asma Ada Di Sekitar Penderita. Retrieved Mei 12, 2012, from KOMPAS: http://kesehatan.kompas.com/read/2012/05/08/22502685/Pencet us.Asma.Ada.di.Sekitar.Penderita

Wardhana, M. (2010). Pengantar Psikoneuroimunologi. Denpasar: Yayasan Institut Bhaktivedanta Indonesia. 